\title{
PENERAPAN PEMBELAJARAN KONTEKSTUAL DENGAN MENGINTENSIFKAN TUTOR SEBAYA DAN MEDIA LINGKUNGAN SEBAGAI UPAYA PENINGKATAN PRESTASI BELAJAR IPA
}

\author{
I Gst. N. Japa 1,*, I Gst. N. Yudha Pustika ${ }^{2}$ \\ 1 Jurusan Pendidikan Guru Sekolah Dasar. Universitas Pendidikan Ganesha, Indonesia \\ 2 Jurusan Pendidikan Guru Sekolah Dasar. Universitas Pendidikan Ganesha, Indonesia
}

\begin{abstract}
Abstrak
Penelitian ini bertujuan untuk mengetahui tingkat prestasi belajar siswa setelah penerapan pembelajaran kontekstual dengan mengintensifkan tutor sebaya dan media lingkungan sebagai upaya peningkatan prestasi belajar IPA pada siswa kelas IV semester I tahun ajaran 2010/2011. Subyek penelitian adalah siswa kelas IV semester I SD No. 4 Selat, Kecamatan Sukasada, Kabupaten Buleleng tahun ajaran 2010/2011 yang berjumlah 23 orang. Jenis penelitian ini adalah jenis penelitian tindakan kelas. Metode yang digunakan dalam penelitian : (1) metode test untuk mengetahui tingkat prestasi belajar siswa. Data yang terkumpul dianalisis dengan (1) metode analisis statistik deskriptif dan (2) metode analisis deskriptif kuantitatif. Penelitian dilaksanakan dalam dua siklus. Hasil penelitian menunjukkan adanya peningkatan (1) pada variabel prestasi belajar terjadi peningkatan dari persentase $67,3 \%$ dengan kategori sedang pada siklus I menjadi 81,7\% dengan kategori tinggi pada siklus II. Dengan demikian dapat disimpulkan penerapan pembelajaran kontekstual dengan mengintensifkan tutor sebaya dan media lingkungan dapat meningkatkan prestasi belajar IPA pada siswa kelas IV.
\end{abstract}

Keywords:

Kontekstual, Tutor

Sebaya, Media, dan

Prestasi

\section{Pendahuluan}

Dalam suasana belajar atau praktek di dalam kelas sering ditemukan beberapa masalah, seperti: siswa acuh tak acuh terhadap materi yang diberikan dan siswa kurang tertarik pada materi pembelajaran IPA. Sehingga proses pembelajaran dalam bidang ipa belum berjalan sesuai dengan tujuan, keadaan ini menyebabkan sulitnya untuk meningkatkan prestasi dalam pembelajaran Ilmu Pengetahuan Alam.

Pada hakekatnya manusia sebagai makhluk Tuhan, telah dilengkapi dengan berbagai potensi dan kemampuan. Pendidikan mempunyai tugas untuk mengembangkan potensi dan kemampuan tersebut secara optimal dan utuh, sehingga memberikan manfaat yang sebesar-besarnya bagi anak yang bersangkutan, bangsa dan negara. Upaya menggali dan mengembangkan potensi anak secara optimal, merupakan tanggung jawab keluarga, sekolah dan masyarakat.

Menurut konsep belajar tuntas (mastery learning), salah satu upaya untuk meningkatkan prestasi anak yang kemampuannya kurang adalah dengan jalan memberikan tambahan waktu belajar yang mandiri. Dalam kenyataan yang kita jumpai, pemberian tambahan waktu belajar di waktu senggang atau di sore hari, justru mendapat respon positif dari anak-anak yang tergolong mampu. Sedangkan bagi anakanak yang kemampuannya kurang, tambahan waktu belajar tersebut dianggap sebagai beban.

Kepuasan seorang guru dalam mengemban misinya mengelola dan melaksanakan proses pembelajaran anak didiknya adalah apabila si guru mampu menciptakan suasana belajar anak yang kondusif serta ditunjang prestasi anak yang baik dan menggembirakan. Bagaimana upaya atau kiat-kiat yang harus dilaksanakari seorang guru untuk mencapai sasaran di atas, menurut seorang guru untuk selalu mengembangkan kreativitas pembelajaran dengan berbagai metode, pendekatan dan atau media sebagai alat bantu, sesuai dengan kondisi. perkembangan anak serta materi bahan ajar yang disajikan.

Masalah-masalah di atas terkait erat dengan penggunaan pendekatan pembelajaran yang kurang 
sesuai dilakukan oleh guru. Dalam memilih atau menetapkan pendekatan pembelajaran, ada tiga prinsip yang perlu diperhatikan (Palupi, 1999), sebagai berikut. 1) Tidak ada satu pendekatan pembelajaran yang unggul untuk semua tujuan. 2) Pendekatan pembelajaran yang berbeda memiliki pengaruh yang berbeda pada hasil pembelajaran. 3) Kondisi pembelajaran yang, berbeda, bisa memiliki pengaruh yang berbeda pada hasil pembelajaran.

Disadari bahwa tidak ada cara yang paling tepat yang dapat menjamin keberhasilan siswa dalam belajar, namun demikian seorang guru dapat menggunakan strategi belajar mengajamya di kelas . Dengan penerapan salah satu pendekatan pembelajaran di kelas maka paling tidak siswa dibuat lebih aktif, karena mereka melakukan suatu kegiatan bagi dirinya.

Tugas guru adalah menciptakan suasana kelas agar terkesan menarik, penyajiannya simpatik sehingga siswa mau mencoba dan melakukan sesuai dengan tujuan yang diinginkan. Salah satu pembelajaran yang dapat dipergunakan adalah pembelajaran kontekstual Dengan mengintensifkan tutor sebaya.dengan pendekatan pembelajaran kontekstual dengan mengintensifkan tutor sebaya diharapkan siswa secara aktif terlibatdalam proses pembelajaran dan siswa belajar dari teman melalui kerja kelompok, diskusi, saling mengoreksi dalam pembelajaran Ilmu Pengetahuan Alam khususnya bagianbagian tumbuhan dan fungsinya.

Berdasarkan uraian di atas, maka peneliti mengkaji tentang pendekatan pembelajaran kontekstual yang dirangkai dalam sebuah judul "penerapan pembelajaran kontekstual dengan mengintensifkan tutor sebaya dan media lingkungan sebagai upaya peningkatan prestasi belajar ilmu pengetahuan alam pada siswa kelas IV SD Negeri 4 Selat.

\section{Metode}

Penelitian ini merupakam penelitian tindakan kelas (classroom action research) yang mengacu pada teori Stephen Kemmis dan Robin Mc. Taggart (dalam FX Sudarsono, 1996) yang terdiri atas 4 komponen, sebagai berikut. 1) Rencana: tindakan apa yang akan dilakukan untuk memperbaiki, meningkatkan dan melakukan perubahan perilaku dan sikap sebagai solusi. 2) Tindakan: apa yang dilakukan oleh guru atau peneliti sebagai upaya perbaikan, peningkatan atau perubahan yang diinginkan. 3) Observasi: mengamati atas hasil atau dampak dari tindakan yang dilaksanakan atau dikenakan terhadap siswa. 4) Refleksi: peneliti mengkaji, melihat dan mempertimbangkan atas hasil atau dampak dari tindakan dari pelbagai kriteria. Berdasarkan hasil refleksi ini peneliti bersamasama guru dapat melakukan revisi terhadap rencana awal.

Subjek penelitian ini adalah 23 orang siswa kelas IV semester II tahun ajaran 2011/2012 SD No. 4 Selat, Kecamatan Sukasada, Kabupaten Buleleng. Sedangkan instrumen pengumpulan data yang digunakan oleh peneliti dalam penelitian tindakan kelas ini adalah metode tes bentuk esay.

Metode tes yang digunakan adalah metode tes uraian (essay). Tes uraian menurut Agung (1999) merupakan "butir tes (soal) yang mengandung pertanyaan atau tugas yang jawaban dan pengerjaan tugas tersebut harus dilakukan dengan cara mengekspresikan pikiran siswa secara tertulis". Alat pengumpulan data berupa butir-butir soal (tes) untuk mengukur prestasi belajar siswa pada mata pelajaran Ilmu Pengetahuan Alam.

Setelah semua data yang diperlukan terkumpul, dilanjutkan dengan analisis data. Dalam menganalisis data digunakan (1) metode analisis statistik deskriptif dan (2) metode analisis kuantitatif.

Analisis deskriptif kuantitatif ini digunakan untuk menentukan persentase tingkat prestasi belajar siswa, dalam mata pelajaran ilmu pengetahuan alam kelas IV yang dikonversikan ke dalam penelitian acuan patokan (PAP) skala 5 setelah penerapan pembelajaran kontekstual dengan mengintensifkan tutor sebaya dan media lingkungan.

Tabel 1. Kriteria PAP Skala 5 adalah sebagai berikut.

\begin{tabular}{cc}
\hline Presentase & Tingkat Hasil belajar \\
\hline $85 \%-100 \%$ & Sangat Tinggi \\
$70 \%-84 \%$ & Tinggi \\
$55 \%-69 \%$ & Sedang \\
$40 \%-54 \%$ & Rendah \\
$0 \%-39 \%$ & Sangat Rendah \\
\hline
\end{tabular}




\section{Hasil Dan Pembahasan}

Siklus I, Pelaksanaan rencana tindakan pada penelitian ini telah disesuaikan dengan tahap-tahap dan prosedur yang telah ditentukan sebelumnya. Berdasarkan pelaksanaan tersebut, data yang diperoleh berupa data hasil evaluasi dengan menggunakan tes esay yang telah dilakukan terhadap siswa selama pelaksanaan penelitian tindakan kelas di siklus 1 .

Setelah pelaksanaan proses belajar mengajar selama siklus I diperoleh data tentang prestasi belajar siswa. yang disajikan ke dalam tabel 2 dibawah ini

Tabel 2 Data Prestasi Belajar Siswa, pada Siklus 1

\begin{tabular}{lccccccccc}
\hline $\begin{array}{l}\text { Kode } \\
\text { Siswa }\end{array}$ & Nilai & $\begin{array}{c}\text { Kode } \\
\text { Siswa }\end{array}$ & Nilai & $\begin{array}{c}\text { Kode } \\
\text { Siswa }\end{array}$ & Nilai & $\begin{array}{c}\text { Kode } \\
\text { Siswa }\end{array}$ & Nilai & $\begin{array}{c}\text { Kode } \\
\text { Siswa }\end{array}$ & Nilai \\
\hline 001 & 7 & 006 & 6 & 011 & 6 & 016 & 6 & 021 & 7 \\
002 & 8 & 007 & 7 & 012 & 7 & 017 & 5 & 022 & 7 \\
003 & 6 & 008 & 8 & 013 & 8 & 018 & 6 & 023 & 6 \\
004 & 9 & 009 & 6 & 014 & 7 & 019 & 6 & & \\
005 & 8 & 010 & 6 & 015 & 7 & 020 & 6 & & \\
\hline
\end{tabular}

Pada siklus I kehadiran siswa mencapai 100\%, yakni sejumlah 23 orang. Berdasarkan tabel di atas diperoleh nilai terendah pada siklus 1 adalah 5 dan nilai tertinggi adalah 9. Berdasarkan hasil analisis yang telah dilakukan maka diperoleh rata-rata presentase prestasi belajar siswa adalah 67,3\% Jika dibandingkan ke dalam pedoman PAP Skala 5 pada tabel 1 maka prestasi belajar siswa kelas IV dalam mata pelajaran IPA pada siklus I tergolong sedang. Berdasarkan hasil tersebut jika dikonversikan kedalam kriteria keberhasilan dalam penelitian ini maka penelitian ini dikatakan belum memenuhi kriteria sehingga perlu dilanjutkan ke siklus 2.

Pelaksanaan siklus 2 dimaksudkan untuk mengatasi kendala-kendala yang masih dihadapi selama siklus 1. Setelah dilakukan perbaikan terhadap kendala yang ditemukan pada siklus 1 maka diperoleh data tentang prestasi belajar siswa siklus 2 yang disajikan ke dalam tabel 3 berikut

Tabel 3 Data Prestasi Belajar Siswa, pada Siklus 2

\begin{tabular}{lllccccccc}
\hline $\begin{array}{l}\text { Kode } \\
\text { Siswa }\end{array}$ & Nilai & $\begin{array}{l}\text { Kode } \\
\text { Siswa }\end{array}$ & Nilai & $\begin{array}{l}\text { Kode } \\
\text { Siswa }\end{array}$ & Nilai & $\begin{array}{c}\text { Kode } \\
\text { Siswa }\end{array}$ & Nilai & $\begin{array}{l}\text { Kode } \\
\text { Siswa }\end{array}$ & Nilai \\
\hline 001 & 8 & 006 & 8 & 011 & 7 & 016 & 8 & 021 & 9 \\
002 & 9 & 007 & 8 & 012 & 9 & 017 & 6 & 022 & 8 \\
003 & 8 & 008 & 8 & 013 & 9 & 018 & 8 & 023 & 7 \\
004 & 10 & 009 & 7 & 014 & 9 & 019 & 7 & & \\
005 & 10 & 010 & 8 & 015 & 8 & 020 & 9 & & \\
\hline
\end{tabular}

Pada siklus II kehadiran siswa siswa mencapai 100\% yakni sejumlah 23 orang. Berdasarkan tabel di atas diperoleh nilai terendah pada siklus 2 adalah 6 dan nilai tertinggi adalah 10. Berdasarkan hasil analisis yang telah dilakukan maka diperoleh rata-rata presentase prestasi belajar siswa adalah $81,7 \%$. Angka rata-rata presen dibandingkan dengan pedoman PAP Skala 5, maka persentase prestasi belajar siswa pada Siklus 2 berada pada kategori 80 - 89 yaitu tinggi.

Sehingga dari kedua siklus yang telah dilaksanakan dapat disimpulkan hasil yang diperoleh seperti tabel 4 berikut.

Tabel 4 Rekapitulasi Hasil PTK

\begin{tabular}{cccc}
\hline Prestasi Belajar & Siklus I & Siklus II & Peningkatan Skor \\
\hline Rata-rata & 6,73 & 8,17 & 1,44 \\
Persentase & $67,3 \%$ & $81,7 \%$ & $14,4 \%$ \\
Katagori & Sedang & Tinggi & \\
\hline
\end{tabular}

Hasil penelitian pada siklus 1 dilihat dari skor rata-rata 6,73 dengan presentase 67,3\% yang di kategorikan sedang.dan pada siklus 2 dilihat dari skor rata-rata 8,17 dengan presentase 81,7\% yang di kategorikan tinggi terjadi peningkatan skor rata-rata 1,44 dengan presentase 14,4\%.peningkatan tersebut disebabkan oleh pembelajaran kontekstual dengan mengintensifkan tutor sebaya dan media lingkungan yang dapat menimbulkan kemampuan berpikir, kreatifitas, pendapat dalam memecahkan masalah, dan dapat merangsang siswa untuk belajar.seperti di tegaskan oleh Suardana (2008) bahwa "model pembelajaran kontekstual dapat meningkatkan keaktifan dan prestasi belajar siswa". Sejalan degan itu 
Agus Budiarmawan (2009) menyatakan " model pembelajaran kontekstual (Contextual Teaching and Learning) dapat meningkatkan aktivitas dan hasil belajar siswa. Dengan demikian bahwa melalui pembelajaran kontekstual akan terjadi peningkatan prestasi belajar siswa secara optimal.

\section{Simpulan Dan Saran}

Berdasarkan hasil penelitian dan pembahasan yang telah diuraikan di muka, maka dapat ditarik kesimpulan bahwa penerapan pembelajaran kontekstual dengan mengintensifkan tutor sebaya dan media lingkungan dalam mata pelajaran IPA pada siswa kelas IV semester II SD No. 4 Selat dapat meningkatkan prestasi belajar siswa yaitu dari kategori sedang menjadi tinggi yaitu dari $67,3 \%$ menjadi $81,7 \%$ yang menunjukkan peningkatan 14,4\%.

Berdasarkan hasil penelittan dapat disampaikan saran-saran berikut. 1) Kepada Siswa diharapkan dengan penerapan pembelajaran kontekstual dalam pembelajaran ilmu pengetahuan alam, dapat lebih menumbuhkan kreatifitas dan peningkatan prestasi dalam pembelajaran ilmu pengetahuan alam. 2) Kepada guru, dalam kegiatan belajar mengajar mata pelajaran IPA khususnya, hendaknya selalu menggunakan berbagai pendekatan dan media yang sesuai dengan pokok bahasan schingga prestasi belajar siswa dapat meningkat. 3) Kepada Sekolah disarankan agar selalu mendukung guru-guru untuk menggunakan berbagai pendekatan dan media untuk meningkatkan prestasi belajar siswa.

\section{Daftar Pustaka}

Agung, A.A. Gede. 1998. Pengantar Evaluasi Pengajaran. Singaraja : Sekola Tinggi Keguruan clan Ilmu Pendidikan.

Agung, A.A. Gede. 1999. Petunjuk Analisis Data Hasil Penelitian Tindakan Kelas. Singaraja Sekolah Tinggi Keguruan dan Ilmu Pendidikan.

Ali, Muhammad. 1992. Guru dalam Proses Belajar Mengajar. Bandung : Sinar Baru. .

Alipandie, Imansyah. 1984. Didaktik Metodik Pendidikan Umum. Surabaya : Usaha Nasional.

Budiarmawan Agus. 2009. Pembelajaran Kontekstual (contextual teaching and Learning) dapatMeningkatkan Aktifitas Mengiring bola. Skripsi (tidak diterbitkan). Jurusan Pendidikan Jasmani, UNDIKSHA Singaraja.

Depdikbud. 1991. Kamus Besar Bahasa Indonesia. Jakarta : Balai Pustaka.

Nurkancana, Wayan dan Sunartana. 1990. Evaluasi Hasil Belajar. Surabaya : Usaha Nasional

Nurkancana, Wayan. dkk. 1998. Psikologi Pendidikan. Singaraja : Biro Penerbitan Fakultas Ilmu Pendidikan Universitas Udayana.

Nurhadi. Dkk. 2004. Pembelajaran Kontekstual. Malang : Universitas Negeri Malang.

Rusyan A. Tabrani. 1993. Proses Belajar Mengajar yang Efektif. Jakarta : Bina Budhaya.

Sadiman, Arief. dkk. 1990. Media Pendidikan. Jakarta : CV Rajawali.

Suardana Putu Gede. 2008. Model Pembelajaran Kontekstual Dapat Meningkatkan Aktivitas dan Hasil Belajar Lari Jarak Pendek. Skripsi (tidak diterbitkan). Jurusan Pendiikan Jasmani, UNDIKSHA Singaraja.

Sudjana, Nana dan Alimad Rivai. 1991. Media Pelajaran. Bandung : Sinar Baru.

Tri Palupi. 1997. Metodologi Pengajaran. Singaraja: STKIP

Undang-Undang Republik Indonesia No. 2 Tahun 1989 Tentang Sistem Pendidikan Nasional dan Penjelasannya. Semarang : Aneka Ilmu . 